\title{
Childhood Acute Myeloid Leukemia with Maturation
}

National Cancer Institute

\section{Source}

National Cancer Institute. Childhood Acute Myeloid Leukemia with Maturation. NCI

Thesaurus. Code C9381.

An acute myeloid leukemia with maturation occurring in children. 